\title{
EFFICACY OF ORGANOPHOSPHORUS DERIVATIVES CONTAINING CHALCONES/ CHALCONE SEMICARBAZONES AGAINST FUNGAL PATHOGENS OF SUGARCANE
}

\author{
S.K. Sengupta*', O.P. Pandey ${ }^{\prime}$, G.P. Rao ${ }^{2}$ and Priyanka Singh ${ }^{1}$ \\ ' Department of Chemistry, DDU Gorakhpur University; Gorakhpur-273009, India \\ Sugar Cane Research station, Kunraghat, Gorakhpur 273008, India
}

\begin{abstract}
Ten newly synthesized organophosphorus derivatives containing substituted chalcones and substituted chalcone semicarbazones were tested for their antifungal efficacy against Colletotrichum falcatum, Fusarium oxysporum, Curvularia pallescens (all sugarcane pathogens). The O,Odiethylphosphate derivatives containing 2-chlorochalcone and 2-chlorochalcone semicarbazone exhibited $70-85 \%$ mycelial inhibition against all the test fungi at $1000 \mathrm{ppm}$. The screening results were correlated with structural features of the tested compounds.
\end{abstract}

\section{INTRODUCTION}

Sugarcane is an important cash crop in many tropical and sub-tropical countries and is one of main sources of sugar production in the world. The crop is highly susceptible to various fungi, bacteria, viruses mycoplasma like organisms and other diseases due to which the yield is greatly reduced ${ }^{1.2}$. Because of their economic importance sugarcane diseases have been studied in great depth from various angles ${ }^{3}$.

Table I. Physical and Analytical Data of the Organophosphorus Derivatives

\begin{tabular}{|c|c|c|c|c|c|c|c|c|}
\hline \multirow[t]{2}{*}{ Cpd } & \multirow{2}{*}{$\begin{array}{c}\text { Yield } \\
(\%)\end{array}$} & \multirow[t]{2}{*}{ Colour } & \multirow{2}{*}{$\begin{array}{l}\text { Decomp. } \\
\text { Temp. } \\
\left({ }^{\circ} \mathrm{C}\right)\end{array}$} & \multirow[t]{2}{*}{ Mol. Formula } & \multicolumn{4}{|c|}{ Analysis: \% Found (Calcd.) } \\
\hline & & & & & $\mathrm{C}$ & $\mathbf{H}$ & $\mathbf{N}$ & $\mathrm{Cl}$ \\
\hline I & 55 & Olive green & 110 & $\mathrm{C}_{19} \mathrm{H}_{22} \mathrm{O}_{5} \mathrm{P}$ & $66.3(66.5)$ & $\begin{array}{c}6.0 \\
(6.1)\end{array}$ & - & - \\
\hline II & 62 & $\begin{array}{l}\text { Yellow } \\
\text { brown }\end{array}$ & 105 & $\mathrm{C}_{19} \mathrm{H}_{22} \mathrm{O}_{5} \mathrm{P}$ & $66.2(66.5)$ & $\begin{array}{c}6.0 \\
(6.1)\end{array}$ & - & - \\
\hline III & 51 & Dark brown & 110 & $\mathrm{C}_{19} \mathrm{H}_{22} \mathrm{O}_{6} \mathrm{P}$ & $63.2(63.5)$ & $\begin{array}{c}5.6 \\
(5.8)\end{array}$ & - & - \\
\hline IV & 57 & Dark yellow & 70 & $\mathrm{C}_{19} \mathrm{H}_{21} \mathrm{O}_{5} \mathrm{ClP}$ & $60.4(60.5)$ & $5.1(5.3)$ & - & - \\
\hline V & 60 & Light brown & 47 & $\mathrm{C}_{20} \mathrm{H}_{24} \mathrm{O}_{6} \mathrm{P}$ & $53.8(54.0)$ & $\begin{array}{c}5.0 \\
(5.1)\end{array}$ & - & - \\
\hline VI & 58 & Dark brown & $\begin{array}{l}\text { Semi } \\
\text { solid }\end{array}$ & $\mathrm{C}_{20} \mathrm{H}_{25} \mathrm{O}_{5} \mathrm{~N}_{3} \mathrm{P}$ & $57.9(58.0)$ & $\begin{array}{c}5.6 \\
(5.8)\end{array}$ & $\begin{array}{c}9.9 \\
(10.0)\end{array}$ & - \\
\hline VII & 55 & Olive green & 80 & $\mathrm{C}_{20} \mathrm{H}_{25} \mathrm{O}_{5} \mathrm{~N}_{3} \mathrm{P}$ & $57.8(58.0)$ & $\begin{array}{c}5.6 \\
(5.8)\end{array}$ & $\begin{array}{c}9.7 \\
(10.0)\end{array}$ & - \\
\hline VIII & 59 & Dark brown & 110 & $\mathrm{C}_{24} \mathrm{H}_{35} \mathrm{O}_{9} \mathrm{~N}_{3} \mathrm{P}_{2}$ & $55.4(55.6)$ & $\begin{array}{c}5.4 \\
(5.6)\end{array}$ & $\begin{array}{c}9.6 \\
(9.7)\end{array}$ & - \\
\hline IX & 55 & Yellow & 95 & $\mathrm{C}_{20} \mathrm{H}_{24} \mathrm{O}_{5} \mathrm{~N}_{3} \mathrm{ClP}$ & $53.2(53.3)$ & $\begin{array}{c}5.0 \\
(5.1)\end{array}$ & $\begin{array}{c}9.1(9 . \\
3)\end{array}$ & $\begin{array}{c}7.7 \\
(7.8)\end{array}$ \\
\hline $\mathrm{X}$ & 60 & Dark brown & $\begin{array}{l}\text { Semi } \\
\text { solid }\end{array}$ & $\mathrm{C}_{21} \mathrm{H}_{27} \mathrm{O}_{6} \mathrm{~N}_{3} \mathrm{P}$ & $56.4(53.3)$ & $\begin{array}{c}5.7 \\
(5.8) \\
\end{array}$ & $\begin{array}{c}9.3(9 \\
4)\end{array}$ & - \\
\hline
\end{tabular}


A number of synthetic organic compounds viz., dithiocarbamates, carbamates, organochlorine, organomercuriale, thiocarbamates and hydrazides are now known to be useful in the control of various fungal diseases in plants ${ }^{4.5}$. Currently we are engaged ${ }^{6-11}$ in synthesizing novel organophosphorus derivatives, which could constitute a new and promising field of application in the national economy. It was realized that on the basis of suitable logic, organic molecules incorporating phosphorus might be designed such that they may be less dangerous in use without losing thesis value as effective pesticides. The present study was therefore undertaken to evaluate the antifungal efficacy of some newly synthesized organophosphorus compounds against various important fungal pathogens of sugarcane.

Table II. IR Spectral Data $\left(\mathrm{cm}^{-1}\right)$ of Organophosphorus Derivatives

\begin{tabular}{|ccccc|}
\hline Compound & $\boldsymbol{V}(\mathbf{C}=\mathbf{O})$ & $\boldsymbol{V}(\mathbf{C}=\mathbf{N})$ & $\boldsymbol{V}(\mathbf{P}-\mathbf{O}-\mathbf{C})$ & $\boldsymbol{V}(\mathbf{P}=\mathbf{O})$ \\
\hline I & $1685 \mathrm{~s}$ & - & $1035 \mathrm{~m}$ & $1290 \mathrm{~m}$ \\
II & $1665 \mathrm{~s}$ & - & $1035 \mathrm{~m}$ & $1290 \mathrm{~m}$ \\
III & $1670 \mathrm{~s}$ & - & $1025 \mathrm{~m}$ & $1280 \mathrm{~m}$ \\
IV & $1675 \mathrm{~s}$ & - & $1030 \mathrm{~m}$ & $1275 \mathrm{~m}$ \\
V & $1680 \mathrm{~s}$ & - & $1030 \mathrm{~m}$ & $1265 \mathrm{~m}$ \\
VI & $1700 \mathrm{~s}$ & $1525 \mathrm{~s}$ & $1020 \mathrm{~m}$ & $1270 \mathrm{~s}$ \\
VII & $1670 \mathrm{~s}$ & $1485 \mathrm{~s}$ & $1025 \mathrm{~m}$ & $1275 \mathrm{~s}$ \\
VIII & $1680 \mathrm{~s}$ & $1475 \mathrm{~s}$ & $1025 \mathrm{~m}$ & $1270 \mathrm{~s}$ \\
IX & $1700 \mathrm{~s}$ & $1510 \mathrm{~s}$ & $1015 \mathrm{~m}$ & $1275 \mathrm{~s}$ \\
X & $1685 \mathrm{~s}$ & $1500 \mathrm{~s}$ & $1020 \mathrm{~m}$ & $1265 \mathrm{~s}$ \\
\hline
\end{tabular}

\section{EXPERIMENTAL}

The reactions of O,O-diethylchlorophosphate were carried out under inert atmosphere and anhydrous conditions. Special precaution were taken to exclude moisture from the apparatus and chemicals as the starting materials (O,O-diethylchlorophosphate) and reactions were susceptible to hydrolysis. Glass apparatus with interchangeable joints were used throughout the work. The solvents were purified and dried using the method described in the literature ${ }^{12}$. O,O-diethylchlorophosphate was prepared according to the reported method ${ }^{13}$. Chalcones/ chalcone semicarbazones were prepared as described ${ }^{4}$. All reactions were carried out in the hood. A hood is a specially constructed workplace that has, at the least, a powered went to suck noxious fumes outside. The details of analysis and physical measurements were the same as reported earlier?.

For antifungal activity all the compounds were tested against all the test fungi by the food poison technique ${ }^{15}$ at three concentrations $(10,100,1000 \mathrm{ppm})$. For this the desired amount of chemical was dissolved in $0.5 \mathrm{~cm}^{3}$ of solvent and mixed with the culture medium on the basis of the volume of medium in each petriplate $\left(80-\mathrm{mm}\right.$ diameter). Oat meal agar medium ${ }^{10}$ was used for all test fungi. In controls, the same amount of medium containing the requisite amount of solvent was poured in place of test chemicals. A mycelial disk (5-mm diameter) obtained from the periphery of 2 week old cultures was taken and transferred to the center of each petriplate. Plates were incubated for 7 days at $28+-2^{0} \mathrm{C}$. Each treatment was repeated three times and the inhibition was a recorded relative to percent mycelial inhibition calculated using the formula.

$$
[(\mathrm{dC}-\mathrm{dT}) / \mathrm{dC}] \times 100
$$

where $\mathrm{dC}$ is the average diameter of the mycelial colony of the control and $\mathrm{dT}$ is the average diameter of the mycelial colony of the treatment .

Synthesis of Organophosphorus derivatives

A mixture of $\mathrm{O}, \mathrm{O}$-diethyl chlorophosphate $(10 \mathrm{mmol})$ and the substituted chalcone / semicarbazones of substituted chalcones $(10 \mathrm{mmol})$ were refluxed in ethyl alcohol $\left(40 \mathrm{~cm}^{3}\right)$ in presence of pyridine $\left(5 \mathrm{~cm}^{3}\right)$ for about $30-40$ hours. The reaction mixture was cooled and poured in ice. The precipitate, thus obtained, was filtered off. The compound was recrystallised from ethanol. 


$$
\text { - }
$$

$\left(\mathrm{C}_{2} \mathrm{H}_{5} \mathrm{O}\right)_{2} \mathrm{PO}(\mathrm{BDH})$

Scheme 1: Synthetic route of O,O-diethylphosphate derivative containing 2-hydroxy chalcone

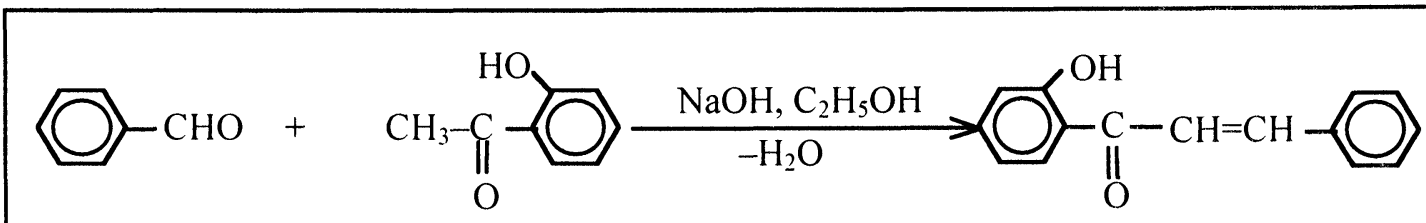

Benzal- 2'-hydroxy acetophenone $(\mathrm{BCAH})$


$\left(\mathrm{C}_{2} \mathrm{H}_{5} \mathrm{O}\right)_{2} \mathrm{PO}(\mathrm{BCA})$

Scheme 2: Synthetic route of O,O-diethyl phosphate derivative containing $2^{\prime}$-hydroxy chalcone 


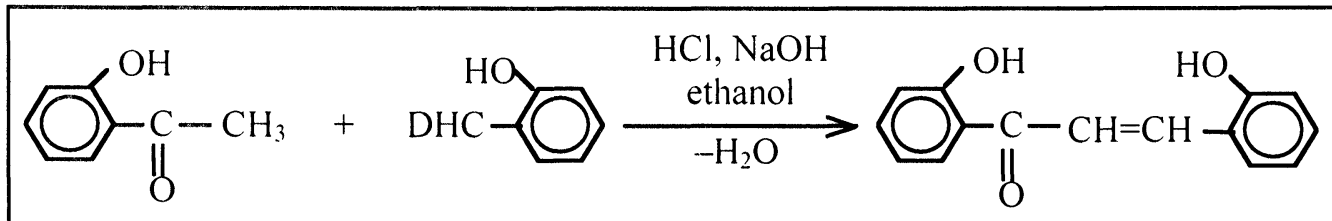

$2,2^{\prime}$-Dihydroxybenzal

acetophenone $\left(\mathrm{BDAH}_{2}\right)$<smiles>CCOP(=O)(Cl)OCCI</smiles><smiles>CCOP(=O)(OCC)Oc1ccccc1C=CC(=O)c1ccccc1OP(=O)(OCC)OCC</smiles>

$\left[\left\{\left(\mathrm{C}_{2} \mathrm{H}_{5} \mathrm{O}\right)_{2} \mathrm{PO}\right\}_{2}(\mathrm{DBA})\right]$

Scheme 3: Synthetic route of O,O-diethylphosphate derivative containing $2,2^{\prime}$-dihydroxy chalcone

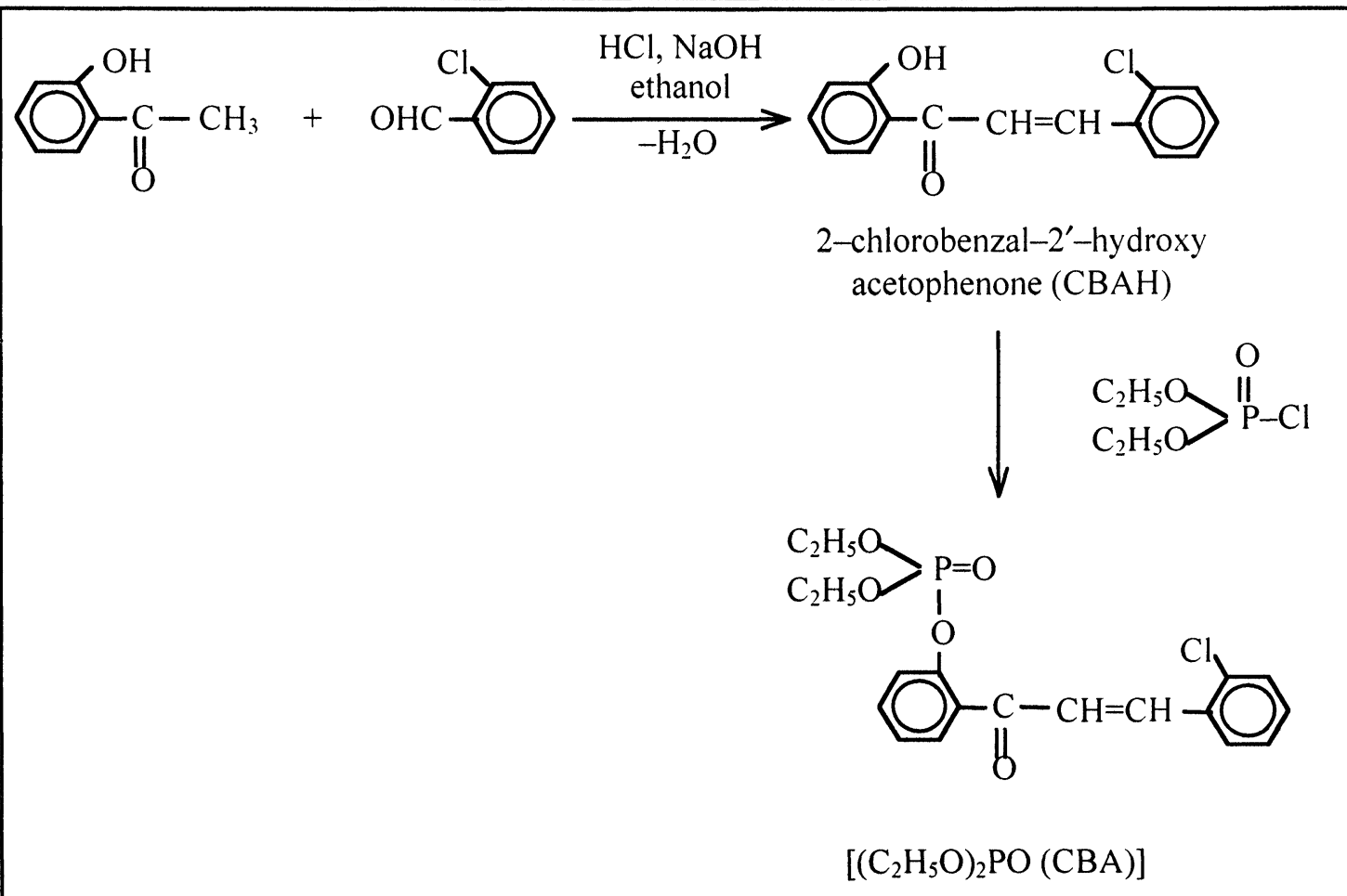

Scheme 4: Synthetic route of O,O-diethyl phosphate derivative containing 2-chloro-2'-hydroxy chalcone 


\section{RESULTS AND DISCUSSION}

The reactions of O,O-diethylchlorphosphate with substituted chalcones, derived by the condensation of 2-hydroxybenzaldehyde and acetophenone; benzaldehyde and 2-hydroxybenzaldehyde; 2hydroxybenzladehyde and 2-hydroxyacetophenone; 2-chlorobenzaldebyde and 2-hydroxybenzaldehyde or 3-methoxybenzaldehyde and 2-hydroxyacetophenone, have been carried out in ethanol in the presence of pyridine and a variety of organophosphorus derivatives (types $\mathbf{I}-\mathbf{V}$ ) have been isolated according to Schemes 1- 5 .

Table III. 'HNMR $(\delta, \mathrm{ppm})$ Data of Organophosphorus Derivatives

\begin{tabular}{|cccccc|}
\hline Cpd & $-\mathrm{CH}=\mathrm{CH}-$ & $\mathrm{CH}_{3}$ & $\mathrm{C}_{2} \mathrm{H}_{5}$ & $-\mathrm{NH}$ & $-\mathrm{NH}_{2}$ \\
\hline I & $6.82(\mathrm{~d}), 5.75(\mathrm{~d})$ & - & $2.75(\mathrm{t}), 3.38(\mathrm{q})$ & - & - \\
II & $6.95(\mathrm{~d}), 5.88(\mathrm{~d})$ & - & $2.60(\mathrm{t}), 3.00(\mathrm{q})$ & - & - \\
III & $7.00(\mathrm{~d}), 5.82(\mathrm{~d})$ & - & $2.80(\mathrm{t}), 3.40(\mathrm{q})$ & - & - \\
IV & $6.85(\mathrm{~d}), 5.90(\mathrm{~d})$ & - & $2.65(\mathrm{t}), 3.26(\mathrm{q})$ & - & - \\
V & $6.80(\mathrm{~d}), 5.86(\mathrm{~d})$ & $1.95(\mathrm{~s})$ & $2.72(\mathrm{t}), 3.35(\mathrm{q})$ & - & - \\
VI & $4.60(\mathrm{~d}), 5.35(\mathrm{~d})$ & - & $2.45(\mathrm{t}), 3.28(\mathrm{q})$ & $5.40(\mathrm{~s})$ & $6.45(\mathrm{~s})$ \\
VII & $4.75(\mathrm{~d}), 5.55(\mathrm{~d})$ & - & $2.55(\mathrm{t}), 3.30(\mathrm{q})$ & $5.48(\mathrm{~s})$ & $6.40(\mathrm{~s})$ \\
VIII & $4.65(\mathrm{~d}), 5.00(\mathrm{~d})$ & - & $2.60(\mathrm{t}), 3.10(\mathrm{q})$ & $5.45(\mathrm{~s})$ & $6.48(\mathrm{~s})$ \\
IX & $4.72(\mathrm{~d}), 5.48(\mathrm{~d})$ & - & $2.50(\mathrm{t}), 3.25(\mathrm{q})$ & $5.50(\mathrm{~s})$ & $6.38(\mathrm{~s})$ \\
X & $4.70(\mathrm{~d}), 5.28(\mathrm{~d})$ & $1.96(\mathrm{~s})$ & $2.58(\mathrm{t}), 3.15(\mathrm{q})$ & $5.42(\mathrm{~s})$ & $6.50(\mathrm{~s})$ \\
\hline
\end{tabular}

The reactions of O,O-diethylchlorphosphate with semicarbazones of substituted chalcones derived by the condensation of 2-hydroxybenzalacetophenone / benzal -2'- hydroxyacetophenone/ 2,2'dihydroxybenzalacetophenone/ 2-chlorobenzal $2^{1}$-hydroxyacetophenone / 3-methoxybenzal-2'hydroxyacetophenone and semicarbazide have been carried out in ethanol in the presence of pyridine and a variety of organophosphorus derivatives (types VI - X) have been isolated according to Schemes $\mathbf{6}-\mathbf{1 0}$.

The analytical data and physical properties of all organophosphorus derivatives are given in Table-I. The methods used for the preparation and isolation of these compounds give materials of good purity as supported by their analysis and TLC. The spectral (IR, ' $H$ NMR) data are given in Tables 2 and 3.

\section{Anti fungal activity}

Results of the antifungal assay of the organophosphorus derivatives are summarized in Table 4. The compounds were screened for their antifungal properties against Colletotrichum falcatum, Fusarium oxysporum, and Curvularia pallescens (all parasitic on sugarcane). Organophosphorus derivatives containing substituted chalcones showed promising results in inhibiting the mycelial growth of all the test fungi. The derivatives containing 2-chlorobenzal-2'-hydroxyacetophenone (IV) showed inhibition upto 84 $\%$ for $C$. falcatum and $80.2 \%$ for $F$. oxysporum at $1000 \mathrm{ppm}$ concentration. Other derivatives showed inhibition 55.1 to $80.3 \%$ against all test fungi at $1000 \mathrm{ppm}$ concentration.

The derivatives containing semicarbazones of substituted chalcones were found to be less active than substituted chalcones. 
Table 4. Fungitoxic Screening Data of Organophosphorus Derivatives

\begin{tabular}{|c|c|c|c|c|c|c|c|c|c|}
\hline \multirow[t]{3}{*}{ Compound } & \multicolumn{9}{|c|}{$\begin{array}{l}\text { Percent Mycelial Inhibition } \\
\text { Compound Dose }(\mathrm{ppm})\end{array}$} \\
\hline & \multicolumn{3}{|c|}{ Colletotrichum falcatum } & \multicolumn{3}{|c|}{ Fusarium oxysporum } & \multicolumn{3}{|c|}{ Curvularia pallescens } \\
\hline & 10 & 1000 & & 10 & 100 & 1000 & 10 & 100 & 1000 \\
\hline I & 40.18 & 58.6 & 78.0 & 31.5 & 44.2 & 68.1 & 30.5 & 44.7 & 65.2 \\
\hline II & 28.6 & 35.6 & 80.1 & 20.0 & 43.2 & 70.3 & 11.6 & 33.3 & 55.1 \\
\hline III & 34.5 & 60.8 & 80.3 & 30.3 & 50.9 & 75.6 & 47.2 & 51.8 & 69.8 \\
\hline IV & 27.6 & 50.4 & 84.0 & 33.3 & 60.6 & 80.2 & 21.7 & 45.9 & 74.2 \\
\hline $\mathrm{V}$ & 25.3 & 40.6 & 80.1 & 22.1 & 50.2 & 78.3 & 12.7 & 50.2 & 68.6 \\
\hline VI & 18.8 & 40.9 & 71.2 & 10.6 & 37.8 & 59.2 & 12.1 & 30.3 & 55.1 \\
\hline VII & 10.7 & 48.2 & 68.1 & 16.7 & 44.3 & 60.6 & 15.0 & 39.8 & 50.3 \\
\hline VIII & 22.8 & 45.2 & 72.1 & 20.1 & 41.3 & 64.2 & 20.2 & 40.3 & 61.2 \\
\hline IX & 25.5 & 49.7 & 73.0 & 22.4 & 46.0 & 62.1 & 15.6 & 39.8 & 62.0 \\
\hline $\mathrm{X}$ & 18.7 & 34.6 & 63.4 & 18.2 & 26.2 & 63.8 & 13.2 & 22.2 & 57.7 \\
\hline
\end{tabular}

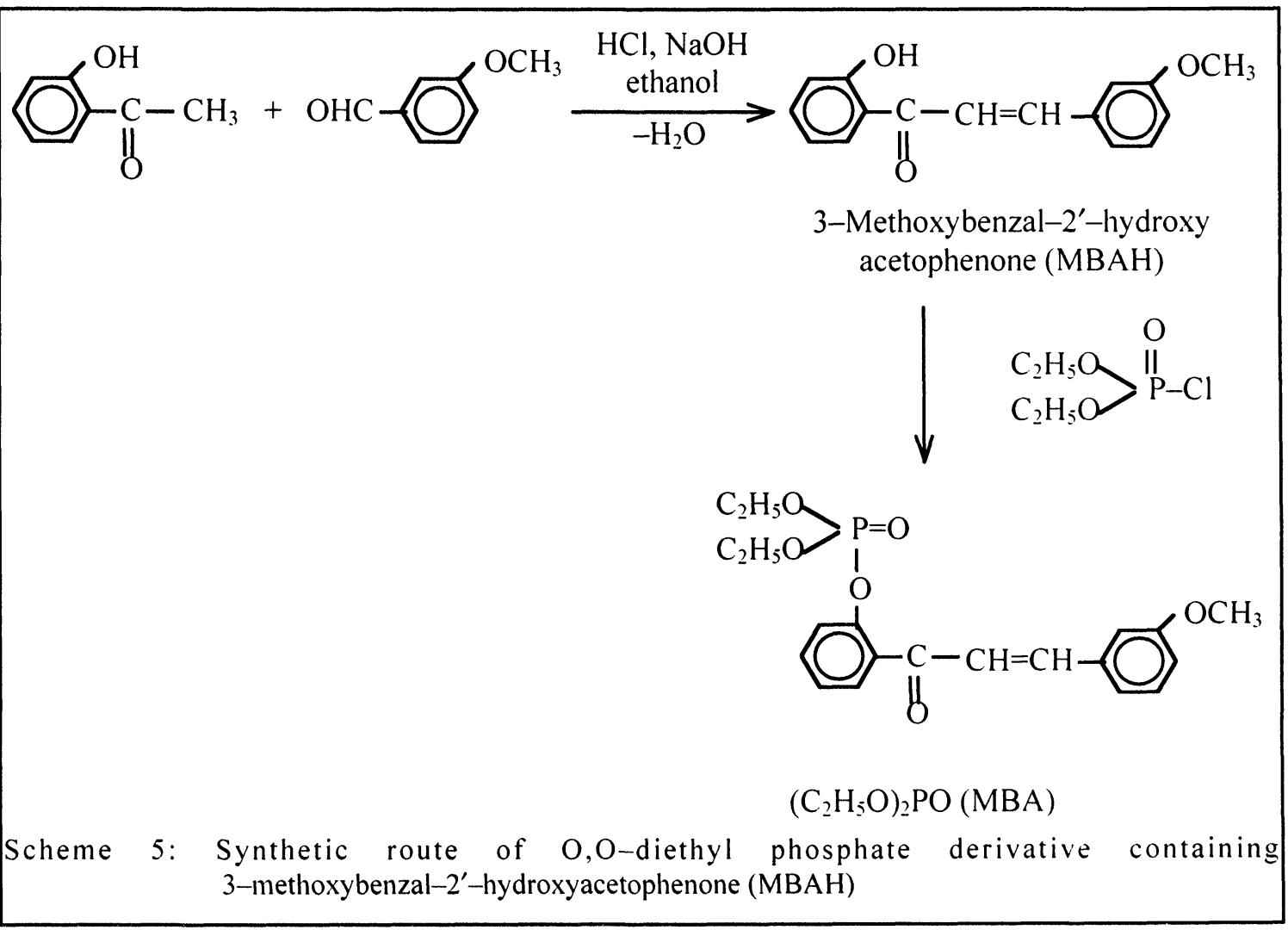




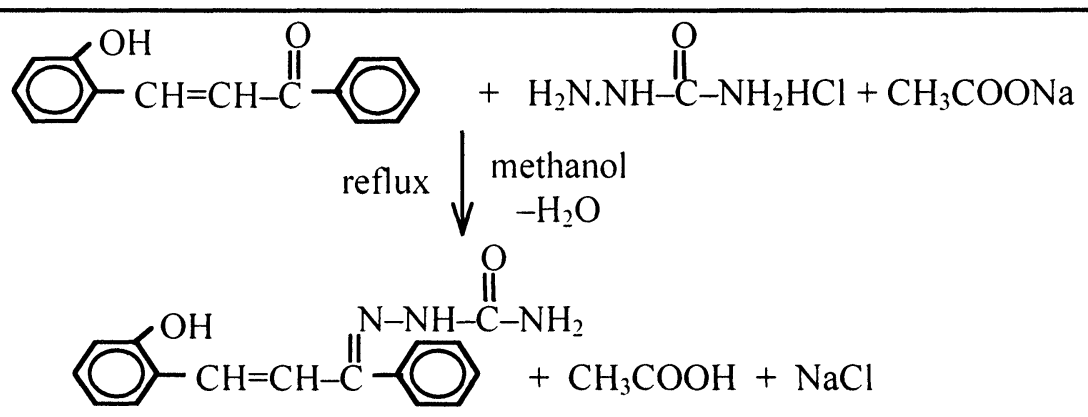

2-Hydroxybenzalacetophenone semicarbazone (BASH)

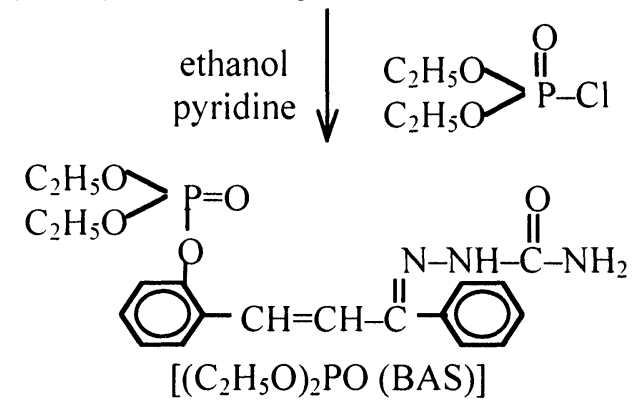

Scheme 6: Synthetic route of $\mathrm{O}, \mathrm{O}$-diethyl phosphate derivative containing 2-hydroxy chalcone semicarbazone.

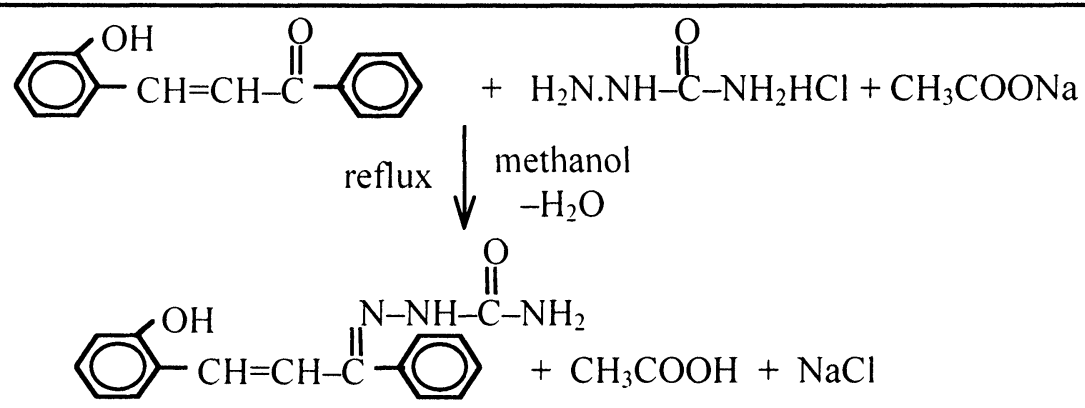

Benzal, $2^{\prime}$-hydroxy benzalacetophenone semicarbazone (BDSH)

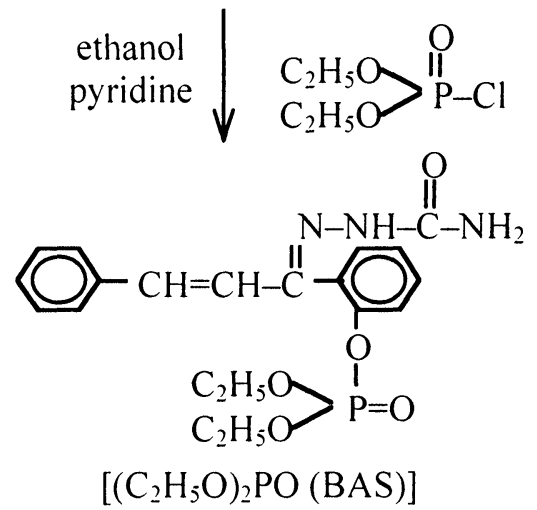

Scheme 7: Synthetic route of O,O-diethyl phosphate derivative containing $2^{\prime}$-hydroxy chalcone semicarbazone. 


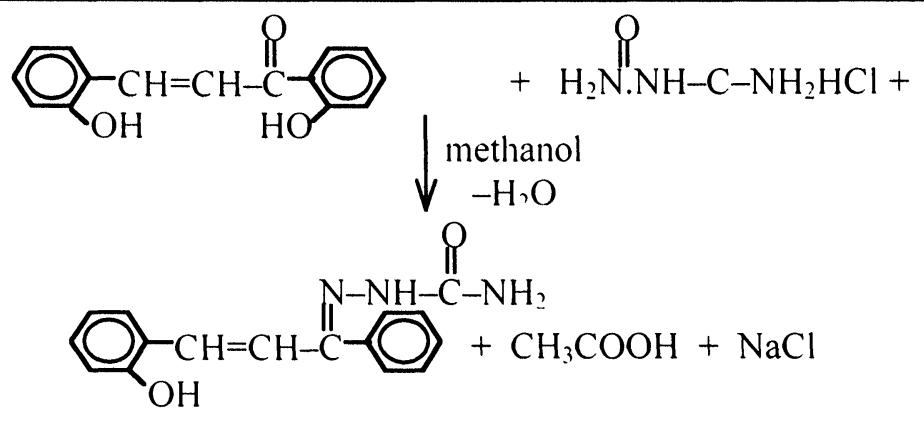

2.2'-Dihydroxybenzalacetophenone semicarbazone $\left(\mathrm{DBSH}_{2}\right)$
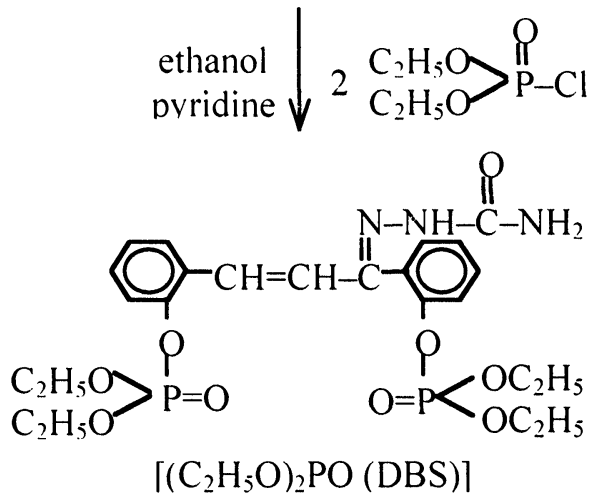

Scheme 8: Synthetic route of O,O-diethyl phosphate derivative containing $2,2^{\prime}$-dihydroxy chalcone semicarbazone.

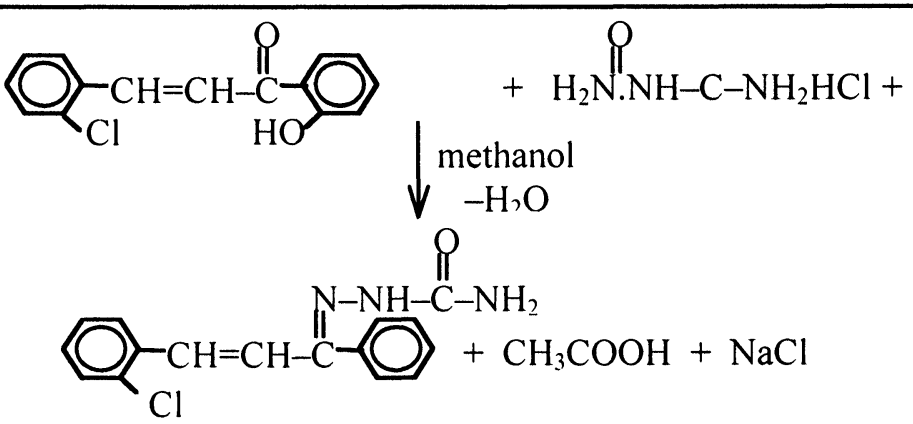

2,2'-Chlorobenzal, 2'-hydroxyacetophenone semicarbazone (CBSH)

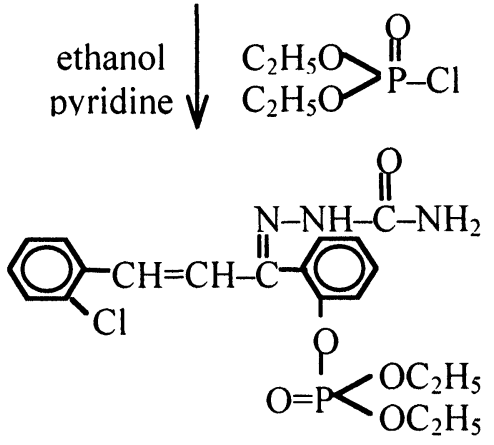

$$
\left\lceil\left(\mathrm{C}_{2} \mathrm{H}_{5} \mathrm{O}\right)_{2} \mathrm{PO}(\mathrm{CBS})\right]
$$

Scheme 9: Synthetic route of $\mathrm{O}, \mathrm{O}-$ diethyl phosphate derivative containing 2-chloro$2^{\prime}$-hydroxy chalcone semicarbazone. 


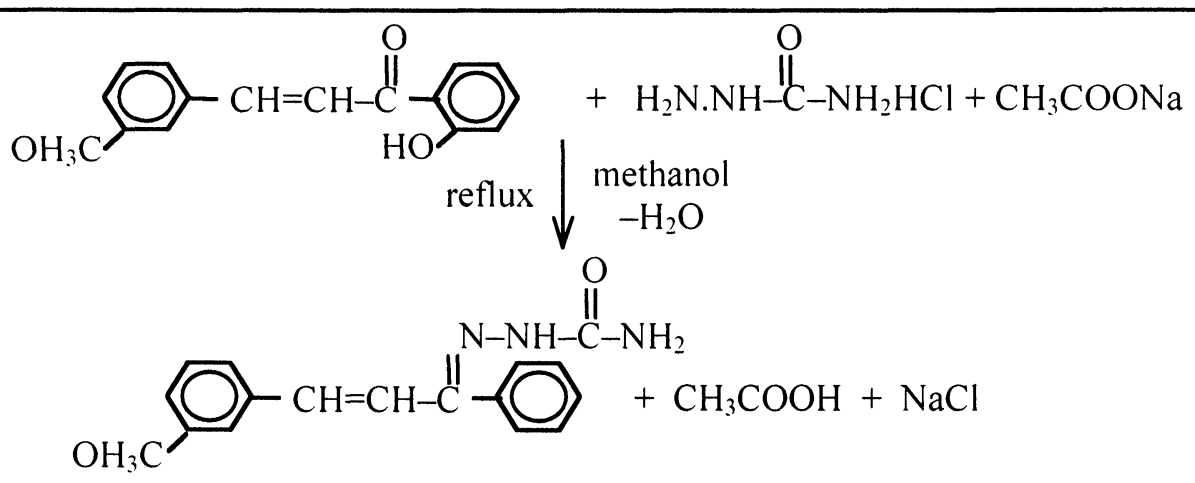

3-Methoxy benzal- 2'-hydroxyacetophenone semicarbazone (MBSH)

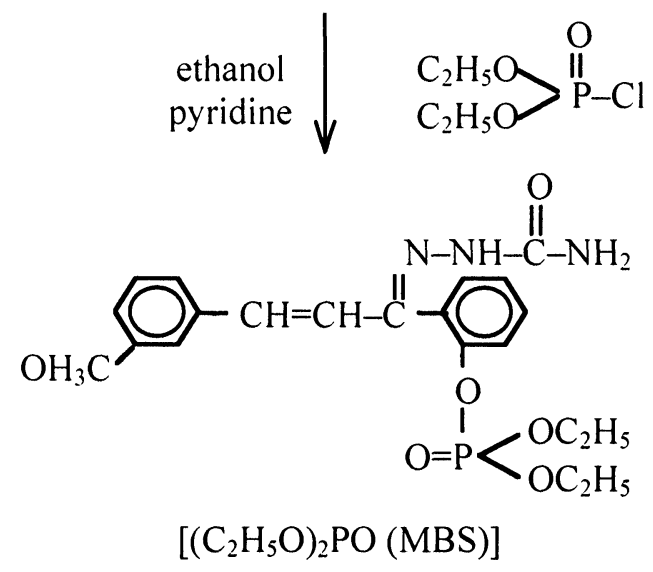

Scheme 10: Synthetic route of O,O-diethyl phosphate derivative containing 3-methoxy-2'-hydroxy chalcone semicarbazone.

The best activity was recorded with O,O-diethylchlorophosphate derivative containing 2chlorobenzal-2'-hydroxyacetophenone semicarbazone (IX). This compound showed activity upto $73.0 \%$ against $C$. falcatum_at $1000 \mathrm{ppm}$ concentration.

Comparing the antifungal activity of different compounds can derive the following conclusions.

(a) There were significant alteration in the antifungal activity with the change in the nature of organic group attached to O,O-diethylchlorophosphate moiety.

(b) For any particular species of fungus, organophosphorus derivatives containing substituted chalcones were found to be more effective than its semicarbozone derivatives.

(c) For any particular series of organic compounds, the compounds containing chloro group in the chalcone ring show better activity.

(d) The activity decreases of dilution.

There results indicate that studies on organophosphorus derivations could be promising as fungicides and constitute a new and promising field of application in disease and pest management.

\section{Acknowledgement}

One of the authors (OPP) is thankful to UGC, New Delhi for financial assistance.

\section{References}

1. C. Recaud, B.T. Eagan, A .G. Gillaspie. C.G. Hughes, Diseases of Sugarcane: Major Diseases, Elsevier, Amsterdam, p. 399 (1989).

2. V.P. Agnihotri and A.K. Srivastava, Current Trends in sugarcane Pathology, International Books \& Periodicals Supply Service, Delhi, p. 235 (1994).

3. V.P. Agnihotri, Diseases of Sugarcane and Sugarbeet, Oxford \& IBH, New Delhi, p 4 (1990).

4. G .P.Rao, P. Kumar, M. Singh, H.N.Singh, O .P. Pandey, Sugarcane, 17 (1994). 
5. G .S. Gruzdyaev, V.A. Zinchenko, V.A . Kalinin, R.I. Slovtsov, The chennical protection of plants, Mir, Moscoe, 1983.

6. K. Chaturvedi, O.P. Pandey and S .K. Sengupta, Synth. React. Inorg. Met.-org . Chem, 24, 1487 (1994).

7. K. Chaturvedi , S .K. Srivastava, O .P. Pandey and S .K. Sengupta, Synth React. Inorg. Met. -Org. Chem., 25, 1191 (1995).

8. K. Chaturvedi, A .K. Jaiswal, O .P. Pandey and S .K. Sengupta, Synth. React. Inorg, Met-org Chem., 25, $1581(1995)$.

9. A. K. Jaiswal, G .P. Rao, O .P. Pandey and S .K. Sengupta, J. Agric. Food. Chem., 46, 1609 (1998) .

10. K. Chaturvedi, A .K .Jaiswal, K.N. Mishra, . O .P. Pandey and S .K. Sengupta, A.C.H. Models in Chem., 135, 93 (1998).

11. S .K. Sengupta, O .P. Pandey, G.P.Rao, S .P. Shahi and A. K. Jaiswal, Sugarcane, 4, 17 (1998).

12. A .I. Vogel, A Text Books of practical organic Analysis, $3^{\text {rd }}$ Ed Longmans, London. 1956.

13. K. Chaturvedi , Ph. D, Thesis, University of Gorakhpur, 1993.

14. A .I. Vogel, A Text Books of Practical organic chemistry., $4^{\text {th }}$ Edn., ( Longmans ; London ), 1978.

15. R.K. Grover and J.D. Moore, Phytopathology, 52, 876 (1962). 